\title{
The Dimensions of Industrial Growth in Tamil Nadu, India: Three Decades of Experience
}

\author{
A. Sankaran ${ }^{1}$, P.Rajkumar ${ }^{2}$ \\ ${ }^{1}$ Assistant Professor, Department of Economics, Pondicherry Central University, INDIA \\ ${ }^{2}$ Assistant Professor, Department of Sociology, Annamalai University, INDIA
}

\begin{abstract}
Industrial development plays a momentous role in all walks of development. The empirical investigations of world famous works pursued by Simon Kuznets(1966) Chennery(1980), Hoffman(1958), Murray E Bryce(1960) and Kaldor(1978) found that there is a positive and significant association between industrial development and overall development of a nation. In this paper an attempt is made to assess the various dimensions of industrial development of Tamil Nadu, India. To examine the performance of the industrial economy of Tamil Nadu, statistics have been collected from Annual Survey of Industries, published by Central Statistical Organization, Government of India. The variables administered in this work to evaluate the performance of agro based and non agro based manufacturing industries of Tamil Nadu include number of factories, productive capital, employment, value of output and value added. This study covers the period of three decades form 1980-81 to 2010-11, so as to understand the effects of the new economic policy. Further, the entire study period has been classified into two folds as pre reform period (1980-81 to 1990-91) and post reform period as (199192 to 2010-11). Collected statistics are deflated using wholesale price index to overcome the price fluctuation. The result obtained using annual compound growth rate reveals that almost all the variables express the same level of growth in both agro and non-agro related industries. But, owing to extraordinary performance of chemical based industries the value added of non-agro related industries reveal a dramatic growth. Mention should be made that the growth of employment has shown a negative sign during the reform period. Hence, it is suggested that the policy makers should frame the effective and suitable policy considering the employment generation. Such kind of strategies will give a new life not only to India but also all the developing countries.
\end{abstract}

Key words: Manufactures, Manufacturing, India JEL Classification Code: O47; L69

\section{INTRODUCTION}

$\mathrm{I}$ ndustrial development plays a key role in the economic development of a nation in general and developing courtiers in particular. The World Bank (1995) rightly remarked that the industrialization is viewed as almost synonymous with development. The empirical evidences of Chennery (1960 \& 1980), Simon Kuznets (1966) Colin Clark (1940), and Taylore (1969) show that industrialization leads to enhance the per capita income and the standard of living through spread effect. In fact, industrial development is an effort in which the underdeveloped countries place a major hope of finding a solution to their problems of poverty, insecurity, and over population and ending their newly realized backwardness in the modern world (Murray \& Bryce, 1960). In addition to this, industrialization of an economy saves foreign exchange, raises output per head, remarkable reduction in cost and drudgery of production process (Slichter, 1961). Development experience of this world demonstrated that no country has achieved sustained economic growth without developing the secondary sector.
According to Kaldor (1978), the driving force behind economic development rests upon the growth of manufacturing sector. In his scholarly research he has highlighted that there is a close significant association between growth of manufacturing output and overall economic growth. Further, the development experience of East and Southeast Asian Economies demonstrates that they have been efficiently participating in the global trade, aided by manufacturing products, led initially by Japan, then by the newly industrializing economies (NIEs) of Hong Kong, China, Korea, Singapore, Taipei, and more recently by the People's Republic of China (PRC). Moreover, in the economy of five members of the Association of Southeast Asian Nations (Indonesia, Malaysia, Philippines, Thailand, and Vietnam), there are some crystal clear spillover effects by industrial development. India has been taking a number of efforts to attain a predominant place in the global manufacturing trade. With the globalization of the economy and implementation of liberal industrial policy reforms, the overall industrial environment at national and state level has become very vibrant due to the spurt in direct investment flow, import of high-tech machines, technology and 
Asian Business Review, Volume 4, Number 1/2014 (Issue 7)

ISSN 2304-2613 (Print); ISSN 2305-8730 (Online)

managerial skills. In India, Tamil Nadu is one of the important icons in terms of industrial development.

\section{Social RELEVANCE Of INDUSTRIALIZATION}

An American economist, Sullivan (2003) pointed out that industrialization is the process of social and economic change that transforms a human group from an agrarian society into an industrial one. It is rightly mentioned in the text book of world history that between 1700 and 1900, industrialization changed the lives of people in Western Europe and the United States. Industrialization has increased dramatically the economic power of Europe and $t$ revolutionized every facet of society, from daily life to life expectancy. Further history shows that due to rapid industrialization in Britain around the 1800s, people enable to earn higher wages in factories than that of cultivation. With this finance, they could afford to heat their homes with coal from Wales and dine on Scottish beef. Further, they purchased better clothing, in England's industrial cities.

In fact, industrialization has a direct and positive impact on the human life. These aspects are well documented in the globally recognized literature that there is a perceptible shift in economic life from village to town, social life becomes dependent upon one another, men are free to utilize their human capital, and a very comfortable life is ensured by better transportation, communication, and mechanized environment. Among these contributions Nettl \& Roland Robertson (1966), and Igor Vrišer (1992), underlined the role of industrialization in social change, Treiman (1986) discussed the effect of industrialization on social stratification. Sickle (1949), Murphy, Shleifer and Vishny (1989) highlighted that underdeveloped countries around the globe considered the industrialization as the solution for all their social and economic ills. Further, the increase in industrial productivity resulting from the use of sophisticated equipments rapidly gained momentum and transformed into a higher standard of living. Greenfield (1961) reported that as a result of urban industrial revolution the modern, small and nuclear families are established in Western Europe and the United States over the course of development. Park (2001) found that in Korea there was an upward mobility in the society, which is entirely different from the experience of European countries of England, France, and Sweden. Further, there was a dramatic change in occupational structure due to industrialization.

The purpose of the present study is to examine the industrial growth that has taken place in Tamil Nadu. This study covers only the registered manufacturing sector - the manufacturing sub-sector with a value added share of about 80 per cent in the industrial sector. It has two broad sub-folds viz., factory sector and non-factory sector. The factory sector referred to as registered under the Indian Factory Act 1948. The non-factory sector or unregistered manufacturing sector consisting of all manufacturing

Copyright (C) 2014, Asian Business Consortium | ABR enterprises, which are not registered under the Indian Factory Act and are not included in this study.

\section{Studies ON INDUSTRIal GROWTH}

There are copious literatures available on industrial growth, expansion, sophistication, and structural transformation in dealing with the theory, policy, practices and its social relevance in both developed and developing countries. A bulk of the analytical literature on industrial sector using stylized analytical tools is available in the form of articles written by eminent scholars and published in the academic journals. The quintessence of the national level studies are presented here. Previous studies in India were done by Ahluwalia (1985), Shetty(1987) Rangarajan (1994), Sandesar (1987), Nagaraj (2003), Balakrishnan \& Suresh Babu (2003), Chaudhuri (2002), and Uma Rani \& Unni (2004), they concentrated on the growth, performance and structural changes of the industrial economy of India and various states. In addition to these, some other studies have concentrated on various dimensions such as special differences with regard to industrial development, impact of competition and FDI flow of industrial economy.

However, studies on agro and non-agro based industries were undertaken by Venkataramaiah \& Burange (2003). They have underlined that the non-agricultural related industries grew at a rate of nearly 11 per cent of output, but the agro based industries undergone 8 per cent of growth during the study period of 1980-81 to 1997-98 in Andhra Pradesh. The non-agro based industries recorded higher rate of growth during the post reform period. Similar study was conducted by Burange (1999) on the industrial economy of Maharashtra covering the period from1979-80 to 1994-95. He revealed that the non-agro based industries show higher rate of growth of 6.6 per cent in respect of value added, while the agro-based industries experienced 4.2 per cent of growth under the period of study. From the sharp of the above studies, the present paper tries to scrutinize the growth of agro and non-agro based industries in the industrial economy of Tamil Nadu during the pre and post reform periods.

\section{Materials and Methods}

The present research has attempted to ascertain the growth of industrial economy of Tamil Nadu. The study period has been classified in to two folds as pre reform (1980-81 to 1990-91) and post reform periods (1991-92 to 2010-11) similar classification was made by Golder (2004), Nagaraj (2003), Venkataramaiah and Burange (2003), Balakrishnan ans Suresh Babu (2003), and Uma Rani \& Jeemol Unni (2004) at all India level. The authentic date on the industrial economy of Tamil Nadu are available only upto 2010-11 in the Annual Survey of Industries (published by CSO, Government of India) which is the principal source for this study. The factors such as Number of Factories, Productive Capital, Number of Persons Employed, Value of Output and Value Added have been used to assess the 
growth of industrial economy of Tamil Nadu. The values are duly weighted and normalized against price fluctuation by using the appropriate wholesale price index. The index of wholesale price for Tamil Nadu is available at 1970-71 base, hence this study used all India whole sale price index of 199394 base, for deflating the two digit group data. Manufacturing industries at two digit level have been classified by Thomas (2002) Venkataramaiah and Burange (2003) Jayasree De (1993), Sudhakar Reddy (1994), Rajeswari (1989), and Thangamuthu (1983) as agro and non-agro related industries. The agro related industries covered from 20-21 to 29 where as the non-agro related industries are embodied remaining all industries (30 to 38), the same procedure is followed in the present study. The annual compound growth rate has been advocated to understand the growth of these industries for the pre and post reform periods. The formula to compute the ACGR is-

$$
A C G R\left(t_{0}, t_{n}\right)=\left(V\left(t_{n}\right) / V\left(t_{0}\right)\right)^{1 / t_{n}-t_{0}}-1
$$

Where, $\mathrm{V}\left(\mathrm{t}_{0}\right)$ - stands for start value, $\mathrm{V}\left(\mathrm{t}_{\mathrm{n}}\right)$ - denotes the final value and $t_{n}-t_{o}-$ is number of years.

\section{AnALYSIS AND Discussion}

The quality of industrial sector has been indicated by its forward and backward linkages. The forward linkages of an industry capture its output that feeds into another industry. For instance, the output of semi-conductor manufacturing unit may serve as an input to computer and photographic equipment manufacturing unit. At the same time, the backward linkage creates demand for suppliers who provide input to industrial units such as automobile manufacturing unit creates demand for tyres, steels, and microprocessors (Alamar \& Murali, 2007). According to various issues of Tamil Nadu An Economic Appraisal the contribution of the manufacturing industries to Tamil Nadu's industrial economy- in 1980-81 the agrorelated industrial group registered 46.5 per cent of value added, the modern industries accounted for 53.5 per cent of value added. In 2002-03, the proportion of agro-related industries declined to 43.7 per cent and the proportion of modern groups improved to 56.3 per cent with respect of value added. In terms of employment generation, the agro-related industries accounted 59 per cent and modern industries provided 40.9 per cent in 1980-81. It should be mentioned that in 2002-03 also the employment generation of agro related and non-agro related industries are more or less gripped in the same place. Similarly, the study conducted by Burange(1999) at all India level concluded that the share of agriculture related industries with regard to fixed capital, employment, value of output and value added had decreased substantially over the study period of 1979-80 to 1994-95, ironically, the nonagro related industries went up.
Table: 1 Annual Average Growth Rate from 1980-81 to 2010-11.

\begin{tabular}{|l|c|c|}
\hline \multicolumn{1}{|c|}{ Characteristics } & Agro-Based & Non-Agro Based \\
\hline Factories & 3.25 & 3.62 \\
\hline Productive Capital & 10.07 & 10.90 \\
\hline Employment & 1.98 & 1.85 \\
\hline Value of Output & 8.14 & 7.95 \\
\hline Value Added & 7.96 & 23.57 \\
\hline
\end{tabular}

Source: Computed from ASI data.

Note: Productive Capital, Output and Value Added are monetary terms and Factories and Number of Persons Employed are in Numbers.

Considering the result of annual compound growth rate, the criterion viz., number of factories, productive capital and employment are nearly same for both agro and non-agro related industries. Surprisingly, the growth rate of output of agro-related industry is slightly higher than that of non- agro related industries. But, with respect to value added, the nonagro related industries revealed a dramatic growth. This appreciable trend is aided by the hasten growth of chemical and chemical producing industries, transport equipment and parts and metal producing industries. While comparing prereform period with the post-reform period, the productive capital and employment are increased in agro based group. Its growth of output is at a stagnant position. All the other characteristics have declined in the reform regime. The leading economists like Ahluwalia and Rangarajan(1994) have stressed that the poor performance of agricultural sector is the causative factor for the sluggish trend of industrial sector in the reform period.

Table: 2 Annual Average Growth Rate of Tamil Nadu Manufacturing

\begin{tabular}{|c|c|c|c|c|}
\hline \multirow[b]{2}{*}{ Characteristics } & \multicolumn{2}{|c|}{ Agro-Based } & \multicolumn{2}{|c|}{ Non-Agro Based } \\
\hline & $\begin{array}{c}\text { Pre-Reform } \\
(1980-81 \text { to } \\
1990-91)\end{array}$ & $\begin{array}{c}\text { Post-Reform } \\
\text { (1991-92 to } \\
2010-11)\end{array}$ & $\begin{array}{c}\text { Pre-Reform } \\
(1980-81 \text { to } \\
1990-91)\end{array}$ & $\begin{array}{c}\text { Post-Reform } \\
(1991-92 \text { to } \\
2010-11)\end{array}$ \\
\hline Factories & \begin{tabular}{l|l}
3.97 & \\
\end{tabular} & 2.45 & \begin{tabular}{l|l}
5.38 \\
\end{tabular} & 1.67 \\
\hline $\begin{array}{l}\text { Productive } \\
\text { Capital }\end{array}$ & 9.21 & 11.03 & 10.69 & 11.13 \\
\hline Employment & 1.70 & 2.29 & 3.66 & -0.17 \\
\hline $\begin{array}{l}\text { Value of } \\
\text { Output }\end{array}$ & 8.08 & 8.20 & 7.70 & 8.22 \\
\hline Value Added & 9.82 & 5.90 & 21.92 & 25.40 \\
\hline
\end{tabular}

Source: Computed from ASI data.

Note: Productive Capital, Output and Value Added are monetary terms, and Factories and Number of Persons Employed are in Numbers.

Based on the non-agro based industries, productive capital and value of output had increased at a snail's phase and the value added had revealed nearly 4 per cent growth from pre to post reform period. It is obvious that the usage of chemicals in all the production process, particularly in agriculture, medicine, textile, matches and photo processing has increased steadily. Mention should be made that the cosmetic industries (by using chemicals) have increased tremendously in the recent periods, which boost up the value added of chemical industries in the 
industrial economy of Tamil Nadu. Conversely, the number of factories revealed a sharp decline and the growth of employment has shown a negative sign during the reform period, the same trend is observed at all India level also Nagaraj(2000). Hence, the down turn trend in the employment generation of overall industrial economy of Tamil Nadu during the reform regime is a matter for serious concern and there is an urgent need to arrest this trend.

\section{Conclusion}

The foregoing analysis of growth of agro and non-agro based industries for the period of three decades starting from 198081 to 2010-11 has yielded the following conclusions. Number of factories, productive capital and employment are nearly same for both agro and non-agro related industries in terms of growth. But, owing to extraordinary performance of chemical based industries the value added of the non-agro related industries revealed dramatic growth for the entire study period.

In the agro-based industries, the growth of productive capital and employment were increased from pre to post reform period, while, all other characteristics are decreased (except output) for the above said periods. In the non-agro based industries, productive capital and value of output had increased at a snail's phase and the value added had revealed a healthy growth from pre to post reform period. Ironically, the number of factories revealed a sharp decline. More importantly, the growth of employment has shown a negative sign during the reform period. The same jobless growth was observed by Ahluwalis(1985), Nagaraj(2000), Chaudhuri (2002) and Venkataramaiah \& Burange(2003) at all India level too. Hence, it is to be suggested that the policy makers should frame effective and suitable policies considering the employment generation. Such kind of strategies will give a new life not only for India but also for all the developing countries.

\section{ACKNOWLEDGEMENT}

We express our heartfelt gratitude to Prof. C. Thangamuthu, Former Vice-Chancellor of Bharathidasan University, Tiruchirappalli, Tamil Nadu, and Dr. Amaresh Samantaraya, Associate Professor, Department of Economics, Pondicherry Central University, Pondicherry, India, for their valuable guidance and suggestions towards the preparation of this research article.

\section{REFERENCE}

A. Sullivan, "Economics: Principles in action- Upper Saddle River". New Jersey, Prentice Hall. P.472, 2003.

B.Goldar, "Indian Manufacturing: Productivity Trends in Preand Post- Reform Periods", Economic and Political Weekly, vol: XXXIX, no.46, pp. 5033-5043. Nov. 2004.

C. Clark, The Conditions of Economic Progress, Macmillan, London, pp. 123-135. 1940.
C.Rangarajan "Industrial Growth: Another Look", Industrial Growth and Stagnation- The Debate in India, Deepake Nayyar, eds, OUP, Bombay, pp 289-317, 1994.

D. J. Treiman, "Industrialization and social Stratification", Sociological Inquiry, vol.40, no.9, pp. 207-234, Jan.2007.

D. Jayasree, "Industrial Pattern of Gujarat", Perspectives on Industrial Development in India, N.K.P. Sinha and M.B. Singh, eds, Deep \& Deep Pub, New Delhi, pp. 61-74, 1993.

H. Park, "Industrialization and Social Mobility in Korea", CDE Working Paper, No. 99-32, University of Wisconsin-Madison, pp. 1-58. Nov. 2001.

H.B. Chenery, "Interaction Between Industrialization and Export", American Economic Review, vol .10, no. 2. Pp. 281-287, Sep.1980.

H.B. Chenery, "Patterns of Industrial Growth", American Economic Review, vol .50, no. 4. pp. 624-654, Sep.1960.

I.J. Ahluwalia, Industrial Growth in India: Stagnation since the Mid-Sixties, Oxford University Press, Delhi, pp. 6582, 1985.

Igor Vrišer, "Industrialization of Slovenia", GeoJournal, vol. 27, no. 4, pp. 365-370. Aug. 1992.

J. V. V. Sickle, "Industrialization and the South", Southern Economic Journal, vol. 15, no. 4, pp. 412-424, Apr. 1949.

J.C Sandesare, "Industrial Growth in India- Performance and Prospects", Studies n Industrial Economy of India, V.S Mahajan, eds, Deep \& Deep, New Delhi, pp. 19-81, 1987.

J.P. Nettl. and Roland Robertson, "Industrialization, Development or Modernization", The British Journal of Sociology, vol. 17, no. 3, pp. 274-291, Sep. 1966.

K. Alamar and N.Murali, "Industrial Sector: An Engine of Growth", Kissan World, vol:34, no:11, pp42-44, Oct. 2007.

K. Venkataramaiah, and L.G. Burange, "Structure and Growth of Industry", Economic and Political Weekly, vol: XXXVII, pp. 1212-1218, Apr. 2003.

L.G.Burange, "Industrial Growth and StructureManufacturing sector in Maharashtra", Economic and Political Weekly, vol: XXXIV, no.9, pp. 39-48, Feb.1999.

L.J. Perry, "Singapore's Rapid Industrialization: A Reassessment", An Interdisciplinary Journal of Southeast Asian Studies, vol. 10, no. 1, pp. 67-76. Dec. 1996.

L.J. Taylore, "Development Patterns: A Simulation Study", The Quarterly Journal of Economics, vol. 83, no. 2, pp. 200241, May. 1969.

M. Kevin, Murphy.K, Andrei Shleifer and R. W. Vishny, “ Industrialization and the Big Push", Journal of Political Economy, vol. 97, no.5, pp. 1003-1026, Oct. 1989.

M.D. Bryce, Industrial developed A guide for accelerating economic growth", The McGraw, London, p. 3, 1960.

N.Kaldor, Further Essays in Economic Theory, Duckworth, London. pp. 156-170,1978.

P. Balakrishinan and M. Suresh Babu, "Growth and Distribution in Indian Industries in the Nineties", Economic and Political Weekly, vol. XXXVIII, no: 38, pp. 3997-4005, Sep.2003.

R. Nagaraj, “Industrial Policy and Performances Since 1980: Which Way Now?", Economic and Political Weekly, vol. XXXVIII, no.35, pp. 3707-3715, Sep.2003. 
R. Nagaraj, "Organized Manufacturing Employment", Economic and Political Weekly, vol. XXXV, no. 38, pp.344548, Oct. 2000.

S. Chaudhri, "Economic Reforms and Industrial Structure in India", Economic and Political Weekly, vol. XXXVI, no. 2, pp.155-162, Jan.2002.

S. Chaudhuri, "Structural Changes and Fluctuations in Manufacturing Factory Secto- A Disaggregative Analysis: 1959-1984-85", Working paper series -121 (89), Indian Institute of Management, Calcutta, pp 1-52. Nov. 1989.

S. Kuznets, Modem Economic Growth: Rate, Structure, and Spread, New Haven: Yale University Press, pp. 1-32. 1966.

S. M. Greenfield, "Industrialization and the Family in Sociological Theory", American Journal of Sociology, vol. 67, no. 3, pp. 312-322, Nov. 1961.
Sudhakar Reddy, "Industrial Performance of Andhra Pradesh", Political Economy of Rural Development, K. Murali Manohar, eds, Kanishka Pub, New Delhi, pp. 177-185, 1994.

Thomas, "A Review on Indian Manufacturing", Indian Development Report, IGIDR, Mumbai. pp. 84-101, Apr. 2002.

Uma Rani and Jeemol Unni, "Unorganized and Organized Manufacturing in India- Potential for Employment Generating Growth", Economic and Political Weekly, vol: XXXIX, no. 41, pp 4568-4580, Oct. 2004.

V.Rajeswari, "Growth and Diversification of Industries, Industrial Development of Andhra Pradesh, J.Manender Reddy, eds, Streling Pub, Bangalore, pp. 122-135, 1989.

World Bank, "Structural and Sectoral Adjustment - World Bank Experience, 1980-92", A World Bank Operations Evaluation Report. Washington, D.C. Oct.1995. 